\title{
Encapsulated Embryogenic Callus of Clitoria ternatea L. for Regeneration and Conservation
}

\author{
Noraini Mahmad, Rosna Mat Taha, Rashidi Othman, Hashimah Elias, and Azani Saleh
}

\begin{abstract}
Encapsulated embryogenic callus of Clitoria ternatea $\mathrm{L}$. were successfully created from leaf explants within 3 weeks after germination on Murashige and Skoog (MS) media. The seeds were initially washed with tap water and teepol, then the seeds were sterilised with $99 \%$ (v/v) sodium hypochlorite solution for 1 minute and rinsed with distilled water three times. In a laminar flow cabinet, the seeds were dipped in $70 \%(\mathrm{v} / \mathrm{v})$ ethanol for 1 minute and blotted with steriled tissue. The $3 \mathbf{~ m m}^{2}$ leaf explants were encapsulated with $3 \%$ alginate $(w / v)$ which were suplemented with various concentrations $\left(0.5-2.5 \mathrm{mg} \mathrm{l}^{-1}\right)$ and combinations of NAA, BAP and adenine. The optimum concentration for the formation of encapsulation matrix was $3.0 \%$ sodium alginate $\left(\mathrm{NaC}_{6} \mathrm{H}_{7} \mathrm{O}_{6}\right)$. Encapsulated beads were soaked in $100 \mathrm{mM}$ calcium chloride dehydrate $\left(\mathrm{CaCl}_{2} .2 \mathrm{H}_{2} \mathrm{O}\right)$ solution for 30 minutes. No suitable beads were formed with low concentration $(1-2 \%)$ of sodium alginate. Within 10 minutes soaking in calcium chloride dehydrate, clear and bead formation with no definite shape was observed. While, within 20 minutes in calcium chloride dehydrate, clear beads, solid and round in shape was observed, however, inside the bead was still in liquid condition. In the present study, the rate of germination of synthetic seeds were slightly decreased from $100 \%$ to $77 \%$ after 60 days of storage at $4^{\circ} \mathrm{C}$. Embryogenic tissue from leaf explants of Clitoria ternatea was distinguished by double staining method with bright red of acetocarmine. This technology is an alternative and supplementary method for regeneration, mass propagation and conservation of this medicinal, attractive ornamental and also forage crop for future uses and exploitation.
\end{abstract}

Index Terms-BAP, encapsulated embryogenic callus, In vitro regeneration, NAA.

\section{INTRODUCTION}

Clitoria ternatea $\mathrm{L}$. is a climber plant that usually grows in various garden hedges. Clitoria ternatea L. or its common name including butterfly-pea, blue-pea, cordofan-pea and Asian pigeon wings, belongs to the family Fabaceae. The United State Development Agency (USDA) intends to conserve Clitoria ternatea $\mathrm{L}$. along with other 16 leguminous

Manuscript received May 19, 2015; revised July 15, 2015. This work was supported by Postgraduate Research Grant, IPPP (PG071/2013B) and University Malaya Research Grant, UMRG (RP025/2012A).

Noraini Mahmad, Rosna Mat Taha, and Hashimah Elias are with the Institute of Biological Sciences, Faculty of Science,University of Malaya, 50603 Kuala Lumpur, Malaysia (e-mail: fara_aid@siswa.um.edu.my, rosna@um.edu.my,shv_03@yahoo.com).

Rashidi Othman is with the International for Halal Research and Training, Herbarium Unit, Department of Landscape Architecture (KAED), International Islamic University Malaysia, 53100 Kuala Lumpur, Malaysia (e-mail: rashidi@iium.edu.my).

Azani Saleh is with the Faculty of Applied Science, MARA University of Technology, 40450 Shah Alam, Selangor, Malaysia (e-mail: azani783@salam.uitm.edu.my). species with potentially useful phytochemicals [1]. It is a strongly persistent, a herbaceous perennial legume with stems fine twining, sparsely pubescent, suberect at base, 0.5-3 m long [2]. In addition, Clitoria ternatea L. is a tropical twining herb, growing wild and also in gardens, bearing white or ink blue flowers resemble a conch-shell. It is widely planted as an ornamental on fencerows. Originally it is selected as a cover crop, but now used for short and medium-term pastures and as green manure, cover crops and protein bank.

Clitoria ternatea contains flavonoids such as quarcetin, kaemferol, robinin and Clitorin. It also contains starch, tannin, resin and anthocyanins [3] and several glycosides including malvidin-3- $\beta$-glycoside, deiphinidin-3- $\beta$-glycoside [4]. In Malaysia, petals of Clitoria ternatea $\mathrm{L}$. or commonly known as 'Bunga Talang' are consumed to make 'Nasi Kerabu' which is blue in colour (natural food dye), and a famous local dish in Malaysia.

The extract of Clitoria ternatea L. was found to have anxiolytic, antidepressant, anticonvulsant and antistress properties [5]. According to the traditional system of medicine 'Aparajita' is considered as a 'Medhya' drug to improve intelligence and enhance memory function [6]. It is also used in the treatment of chronic bronchitis, dropsy, goiter, leprosy, mucous disorders, sight weakness, skin diseases, sore throat and tumors. In Ayurveda Indian medicine, the roots are most widely used and are bitter, refrigerant, laxative, intellect promoting, diuretic, anthelmintic and as tonic. This root is useful in dementia, burning sensation, inflammation and asthma. The seeds are cathartic, while the leaves are used in otalgia and hepatopathy. Besides, the roots, stems and flowers are recommended for the treatment of snakebite and scorpionsting. The phytochemical investigations revealed the presence of saponins, carbohydrates, alkaloids, proteins, anthroquinones and phytosterols. It is used as diuretics, antihelmintic, antidiabetic, antipyretic and brain tonic [7], [8]

In vitro propagation is a viable alternative for a species which is difficult to regenerate by conventional methods; where populations have decreased due to over exploitation by destructive harvesting and can effectively be used to meet the growing demand for clonally uniform elite plants. Therefore, the measures to develop micropropagation protocols for elite stocks of Clitoria ternatea L. are urgently needed. The development of encapsulated or synthetic seed technology brings up a new prospect in agriculture and floriculture industry. The aims of this paper are to produce artificial seeds and to investigate the ability of the synthetic seeds to regenerate within 90 days of storage at low temperature (4 \pm $\left.1^{\circ} \mathrm{C}\right)$. 


\section{MATERIALS AND METHODS}

\section{A. Production of Synthetic Seeds of Clitoria Ternatea L.}

\section{1) Explant sources}

Leaf explants of Clitoria ternatea L. obtained from 3-week-old seedling were cultured on MS medium supplemented with different concentrations of NAA (0.5-2.5 $\mathrm{mg} \mathrm{l}^{-1} \mathrm{NAA}$ ), added with $0.5 \mathrm{mg} \mathrm{l}^{-1} \mathrm{BAP}$ and $40 \mathrm{mg} \mathrm{l}^{-1}$ adenine. The cultures were incubated and maintained at $25 \pm 1^{\circ} \mathrm{C}$ with 16 hours light and 8 hours dark. Thirty replicates for each treatment were prepared for three times repetition. Illumination was at 1000 lux and relative humidity was 90-100\%.

\section{2) Preparation of $3 \%(w / v)$ sodium alginate solution $\left(\mathrm{NaC}_{6} \mathrm{H}_{7} \mathrm{O}_{6}\right)$}

The standard method for preparation of capsule matrix was followed [9]. To prepare $3 \%(\mathrm{w} / \mathrm{v})$ sodium alginate solution in $100 \mathrm{ml}$ MS basal medium without calcium chloride dehydrate $\left(\mathrm{CaCl}_{2} \cdot 2 \mathrm{H}_{2} \mathrm{O}\right), 1 \mathrm{~g}$ sodium alginate powder was dissolved gradually. Sucrose (3.0 g) and hormones (NAA, BAP and adenine) were added. Media $\mathrm{pH}$ was adjusted to 5.8. This solution was autoclaved for 20 minutes at $121^{\circ} \mathrm{C}$ and $104 \mathrm{kpa}$.

3) Preparation of calcium chloride dehydrate solution $\left(\mathrm{CaCl}_{2} \cdot 2 \mathrm{H}_{2} \mathrm{O}\right)$

Calcium chloride dehydrate solution was used as a complexion agent. To prepare $75 \mathrm{mM}(\mathrm{w} / \mathrm{v})$ calcium chloride dehydrate in $100 \mathrm{ml}$ distilled water, $1.47 \mathrm{~g} \mathrm{CaCl}_{2} .2 \mathrm{H}_{2} \mathrm{O}$ was dissolved gradually. This solution was autoclaved for 20 minutes at $121^{\circ} \mathrm{C}$ and $104 \mathrm{kpa}$.

\section{4) Encapsulation techniques and bead formation}

The leaf explants were encapsulated (hardened) by allowing them to remain in $\mathrm{CaCl}_{2} \cdot 2 \mathrm{H}_{2} \mathrm{O}$ solution for 30 minutes. These beads were taken out and transferred into the sterile distilled water to wash out the excess $\mathrm{CaCl}_{2} \cdot 2 \mathrm{H}_{2} \mathrm{O}$ solution and were blotted with sterile tissue paper. The beads were then cultured on solid MS media at $25 \pm 1^{\circ} \mathrm{C}$ under 16 hours light. Thirty replicates for each treatment were prepared for three experiments.

\section{5) Low temperature storage}

Steriled encapsulated beads of Clitoria ternatea L. were stored on solid MS basal medium under dark condition (wrapped with aluminium foil) at low temperature $\left(4 \pm 1^{\circ} \mathrm{C}\right)$. The survival rates were recorded for 90 days. Thirty replicates for each treatment were prepared for three experiments.

\section{B. Identification of Embryonic Callus Using Double Staining Method}

\section{1) Preparation of $2 \%$ acetocarmine}

Glacial acetic acid $(45 \mathrm{ml})$ was added to $55 \mathrm{ml}$ distilled water in a conical flask ( $45 \%$ acid solution). $2 \mathrm{~g}$ of carmine were weighed out and added to $45 \%$ acid solution. The flask was placed on a hot plate in the fume hood and boiled gently for 5 minutes. The cooled solution was filtered using Whatman filter paper and stored at room temperature.

\section{2) Preparation of $0.5 \%$ evan's blue}

Evan's Blue powder $(0.5 \mathrm{~g})$ was added to $100 \mathrm{ml}$ distilled water in a conical flask. The flask was then capped and swirled by hand to mix the solution.

\section{3) Double staining method}

Callus $\left(3 \mathrm{~mm}^{2}\right)$ was placed on a glass slide. A few drops of $2 \%$ acetocarmine was added to the callus. The callus then was gently divided into very small pieces in the acetocarmine using a needle. The slide was held with forceps and heated over a low flame for a few seconds. Then, the callus was washed 2 to 3 times with distilled water and all liquid were removed. Two or three drops of Evan's Blue were added to acetocarmine stained cells and after 30 seconds the stained cells were washed 2 to 3 times with water and all the water was removed. One or two drops of glycerol was added to the stained cells to prevent the preparation from drying. The specimen was then observed under the microscope.

\section{4) Acclimatization}

After six months in cultures (in vitro), all regenerated plantlets (complete with roots and shoots) were transferred to different substrates (sterilled and non-sterilled black garden soil) for further growth and development.

\section{5) Data analysis}

All experiments were conducted using a completely randomized design. Data collected were statistical analyzed using Duncan's Multiple Range Test (DMRT). Mean with different letters in the same column differ significantly at $p<0.05$.

\section{RESUlTS AND DISCUSSION}

The current study resulted in compact green callus formation from leaf explants cultured on MS media supplemented with various combinations and concentrations of NAA, $0.5 \mathrm{mg} / \mathrm{l} \mathrm{BAP}$ and $40 \mathrm{mg} / \mathrm{l}$ adenine (Table II). The 3 $\mathrm{mm}^{2}$ leaf explants were excised from 3-week-old germinating seedlings on MS basal media. The highest $(0.83+0.17 \mathrm{~g})$ of dry callus formation per explant was obtained on solid MS media supplemented with combination of $1.0 \mathrm{mg} / \mathrm{l}$ NAA, 0.5 $\mathrm{mg} / \mathrm{l} \mathrm{BA}$ and $40 \mathrm{mg} / \mathrm{l}$ adenine, after 2 weeks. The shoots formed after 12 weeks. In previous study [10], reported that the highest frequency of productive shoot regeneration (red calyx, $8.5 \%$ ) was obtained within 8 weeks from explants of immature inflorescence cultured on MS medium supplemented with $1.0 \mathrm{mg} / \mathrm{l}$ benzyl amino purine (BA) and $1.0 \mathrm{mg} / 1$ 1-naphthalene acetic acid (NAA), added with $40 \mathrm{mg} / \mathrm{l}$ adenine and $3 \%$ sucrose. The current result was followed by $0.31+0.62 \mathrm{~g}$ dry weight of callus per explant on solid MS basal media after 4 weeks. Whilst, the lowest $(0.15+0.77 \mathrm{~g})$ was obtained on MS media supplemented with combinations of $2.5 \mathrm{mg} / \mathrm{l} \mathrm{NAA}, 0.5 \mathrm{mg} / \mathrm{l} \mathrm{BA}$ and $40 \mathrm{mg} / \mathrm{l}$ adenine after 8 weeks. [11] reported the micropropagation of Clitoria ternatea $\mathrm{L}$. on DKW medium with maximum number of shoots was achieved in DKW medium containing $1 \mathrm{mg} / \mathrm{l} \mathrm{BAP}$ and the maximum number of roots multiplication was achieved in DKW medium containing $2.0 \mathrm{mg} / \mathrm{l}$ NAA.

Based on Table II, combination of $1.0 \mathrm{mg} / \mathrm{l} \mathrm{NAA}, 0.5 \mathrm{mg} / \mathrm{l}$ $\mathrm{BA}$ and $40 \mathrm{mg} / \mathrm{l}$ adenine was added to $3 \%$ sodium alginate solution to produce synthetic seed of Clitoria ternatea. Initially, embryogenic tissue from leaf explants was distinguished by double staining method (Fig. 1). Basically, 
all embryogenic cells had large nuclei and dense cytoplasms. These nuclei stained intensed bright red with acetocarmine. According to [12] genetic improvement through transgenic technology is impended due to non-availability of efficient regeneration system in many grain legumes. Embryogenic system offers an ideal tool for in vitro production and selection of transgenic plants. However, only after 3 months, the compact green callus changed to shoots formation. According to [13], the inclusion of cytokinins and auxin caused swelling at the bases of explants over 6-10 days of culture and the addition of a cytokinins and auxin to a medium was essential to induce axillary shoot proliferation. The concentration and type of cytokinin together with auxin used significantly affected the number of shoot, number of nodes and length of shoot regeneration. Based on [14], identified that the proliferation of shoots was achieved on MS medium supplemented with various concentrations of 6-benzyladenine (BA), Kinetin (Kin) and 2-isopentenyl adenine (2-iP) either singly or in combination with a-naphthalene acetic acid (NAA). According to [15], optimum embryogenic callus (75\%) was induced from cotyledonary explants on [16] Murashige and Skoog, (MS) medium supplemented with 2 $\mathrm{mg} / \mathrm{l}$ 2, 4-dichlorophenoxyacetic acid (2, 4-D), followed by subculturing the callus on MS medium supplemented with 2 $\mathrm{mg} / \mathrm{l}$ 6-benzyladenine (BA) and $0.5 \mathrm{mg} / \mathrm{l} \alpha$-naphthalene acetic acid (NAA).

The current study shows that different concentrations of sodium alginate $\left(\mathrm{NaC}_{6} \mathrm{H}_{7} \mathrm{O}_{6}\right)$ and soaking duration of calcium chloride dehydrate $\left(\mathrm{CaCl}_{2} \cdot 2 \mathrm{H}_{2} \mathrm{O}\right)$ influenced the bead formation of Clitoria ternatea. With sterile condition, leaf explants encapsulated using sodium alginate solution for beads formation with ideal texture with uniform, isodiametric shape and size. The optimum concentration for the formation of encapsulation matrix was $3.0 \%$ sodium alginate $\left(\mathrm{NaC}_{6} \mathrm{H}_{7} \mathrm{O}_{6}\right)$. Encapsulated explants were soaked in calcium $100 \mathrm{mM}$ chloride dehydrate $\left(\mathrm{CaCl}_{2} \cdot 2 \mathrm{H}_{2} \mathrm{O}\right)$ solution for 30 minutes (Fig. 2). No suitable beads were formed with low concentration (1-2\%) of sodium alginate. No definite shape of beads were formed within 10 minutes soaking in calcium chloride dehydrate. While, after 20 minutes in calcium chloride dehydrate, beads were clear, solid and round at outside, however, inside bead was still with liquid condition which caused problems when the beads were cultured on solid MS basal media, the beads became shrunk and explants died. The optimum soaking period was 30 minutes in calcium chloride dehydrate with high concentration of $3 \%$ sodium alginate which formed very hard beads but perfect round shape. Then, the beads (containing sodium alginate supplemented with $1.0 \mathrm{mg} / \mathrm{l} \mathrm{NAA}, 0.5 \mathrm{mg} / \mathrm{l} \mathrm{BA}$ and $40 \mathrm{mg} / \mathrm{l}$ adenine) were cultured for 4 weeks on the same MS solid media (MS medium supplemented with $1.0 \mathrm{mg} / \mathrm{l}$ NAA, 0.5 $\mathrm{mg} / \mathrm{l} \mathrm{BA}$ and $40 \mathrm{mg} / \mathrm{l}$ adenine) as the basis. The callus formed after 2 weeks and shoots were formed after 12 weeks. Finally, the beads were transferred to MS basal medium for another 4 weeks for root formation.

The survival rate of synthetic seeds on MS media (viability for every 15 days of storage) was shown in Table II. The current study resulted in the highest survival rate of synthetic seeds of Clitoria ternatea (100\%) on MS media supplemented with combination of $1.0 \mathrm{mg} / \mathrm{l} \mathrm{NAA}, 0.5 \mathrm{mg} / \mathrm{l}$ BA and $40 \mathrm{mg} / \mathrm{l}$ adenine compared to $92 \%$ on MS medium supplemented with $2.0 \mathrm{mg} / \mathrm{l} \mathrm{BA}$ and $0.5 \mathrm{mg} / \mathrm{l} \mathrm{NAA} \mathrm{[14].}$ However, the survival rate was decreased to the lowest $(53.33 \pm 1.22 \%)$ after 90 days, while [15] reported the synthetic seeds kept at $4{ }^{\circ} \mathrm{C}$ showed $86 \%$ viability even after 5 months of storage. In addition, according to [17], after breaking dormancy at $4 \pm 1^{\circ} \mathrm{C}$ for 6 weeks, most of seedlings from somatic embryos developed into healthy plants in culture room at $24 \pm 1^{\circ} \mathrm{C}$.

TABLE I: The CALlus Formation OF CLITORIA TERNATEA L. FROM LEAF EXPLANTS ON SOLID MS MEDIA SUPPLEMENTED WITH DIFFERENT COMBINATIONS OF NAA, BAP AND ADENINE AT $25+10^{\circ} \mathrm{C}$ WITH 16 HOURS LIGHT AND 8 HOURS DARK, WITH 1000 LUX INTENSITY OF LIGHT

\begin{tabular}{|c|c|c|}
\hline MS + Hormones $\left(\mathrm{mg} \mathrm{l}^{-}\right)$ & $\begin{array}{l}\text { Dry weight, g (mean } \\
\pm \mathrm{SE})\end{array}$ & Observation \\
\hline MSO & $0.31 \pm 0.62^{\mathrm{a}}$ & $\begin{array}{l}\text { Compact green } \\
\text { callus formation } \\
\text { after } 4 \text { weeks }\end{array}$ \\
\hline $\begin{array}{l}\mathrm{MS}+0.5 \mathrm{mg} / 1 \mathrm{NAA}+0.5 \mathrm{mg} / 1 \\
\mathrm{BA}+40 \mathrm{mg} / \mathrm{l} \text { adenine }\end{array}$ & $0.27 \pm 0.43^{\mathrm{a}, \mathrm{b}}$ & $\begin{array}{l}\text { Compact } \\
\text { green callus } \\
\text { formation } \\
\text { after 6 weeks }\end{array}$ \\
\hline $\begin{array}{l}\mathrm{MS}+1.0 \mathrm{mg} / 1 \mathrm{NAA}+0.5 \mathrm{mg} / \mathrm{l} \\
\mathrm{BA}+40 \mathrm{mg} / \mathrm{l} \text { adenine }\end{array}$ & $0.83 \pm 0.17^{\mathrm{a}}$ & $\begin{array}{l}\text { Compact green } \\
\text { callus formation } \\
\text { after } 2 \text { week }\end{array}$ \\
\hline $\begin{array}{l}\mathrm{MS}+1.5 \mathrm{mg} / \mathrm{l} \mathrm{NAA}+0.5 \mathrm{mg} / 1 \\
\mathrm{BA}+40 \mathrm{mg} / \mathrm{l} \text { adenine }\end{array}$ & $0.20 \pm 0.32^{\mathrm{b}}$ & $\begin{array}{l}\text { Compact green } \\
\text { callus formation } \\
\text { after } 7 \text { weeks }\end{array}$ \\
\hline $\begin{array}{l}\mathrm{MS}+2.0 \mathrm{mg} / 1 \mathrm{NAA}+0.5 \mathrm{mg} / 1 \\
\mathrm{BA}+40 \mathrm{mg} / \mathrm{l} \text { adenine }\end{array}$ & $0.25 \pm 0.12^{b}$ & $\begin{array}{l}\text { Compact green } \\
\text { callus formation } \\
\text { after } 6 \text { weeks }\end{array}$ \\
\hline $\begin{array}{l}\mathrm{MS}+2.5 \mathrm{mg} / \mathrm{l} \mathrm{NAA}+0.5 \mathrm{mg} / \mathrm{l} \\
\mathrm{BA}+40 \mathrm{mg} / \mathrm{l} \text { adenine }\end{array}$ & $0.15 \pm 0.77^{\mathrm{c}}$ & $\begin{array}{l}\text { Compact green } \\
\text { callus formation } \\
\text { after } 8 \text { weeks }\end{array}$ \\
\hline
\end{tabular}

*Each value represents the mean \pm SE of 30 replicates. The mean with different letters in the same column differ significantly at $p \leq 0.05$.

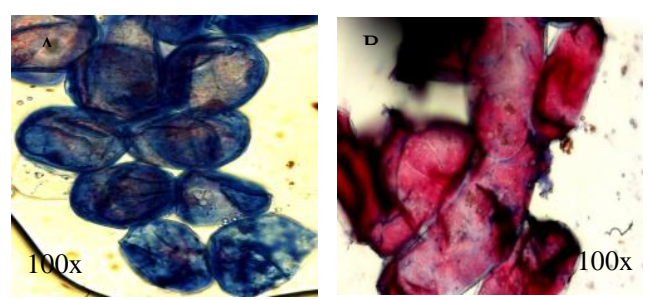

Fig. 1. Embryogenic calli from leaf explants from double staining method observed with camera lens as the calli stained intense bright red with acetocarmine, A) Non-embryogenic cell with blue nucleus at magnification 100x, B) clearer somatic embryogenesis cell with red nucleus at magnification $100 \mathrm{x}$.

The resulting plantlets were then subsequently transferred to soil and acclimatized on different substrates (sterilled and non-sterilled black garden soil) for further growth and development (Table III and Fig. 3). From previous studies, [18] were successful in sowing Hibiscus moscheutos directly into a greenhouse. The current study only shows positive response on encapsulated leaf explants on solid MS media supplemented with $1.0 \mathrm{mg} / \mathrm{l} \mathrm{NAA}, 0.5 \mathrm{mg} / \mathrm{l} \mathrm{BA}$ and $40 \mathrm{mg} / \mathrm{l}$ adenine. Unfortunately, encapsulated beads became shrunk and contaminated on sterilled and non-sterilled black garden soil. According to [19], in vivo growth of encapsulated 
axillary buds of mulberry (Morusindica L.) supplemented with additional fungicide to the alginate beads prevented contamination of the buds and increased survival of the buds when sown in soil. [20] also observed that addition of fungicide $(0.1 \%$ carbendazim) and bacteriocide $(0.1 \%$ streptomycin) into the encapsulating gel reduced the incidence of fungal and bacterial contamination to a minimum level and nearly $95 \%$ of the beads remained healthy. After six months being acclimatized, vivid blue colour of flower were formed the same as mother plant (Fig. 3).
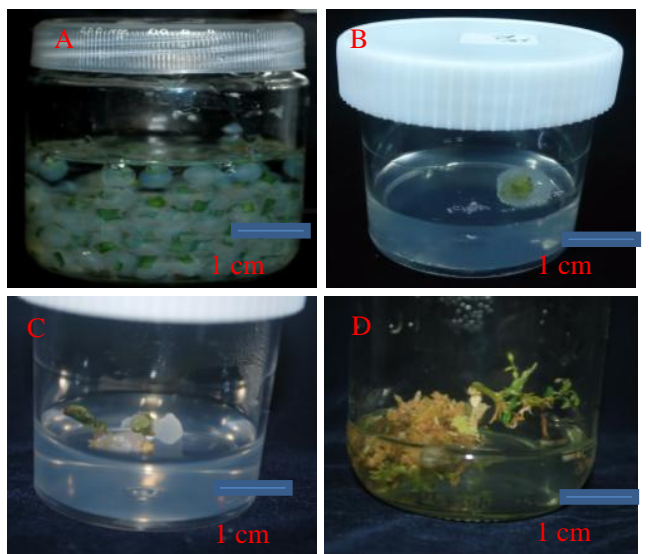

Fig. 2. Sodium alginate encapsulated leaf explants being stored at $4 \pm 1^{\circ} \mathrm{C}, \mathrm{A}$ ) encapsulated leaf soaked in calcium chloride for 30 minutes, B) cloudy, solid and round bead of encapsulated callus, C) Surviving encapsulated or synthetic seeds after 90 days in storage, D) multiple shoots formation and elongation.

TABLE II: EFFECT OF STORAGE PERIOD ON GERMINATION RATE OF CLITORIA TERNATEA L. AT $4 \pm 1^{\circ} \mathrm{C}$ (SODIUM AlginATE ENCAPSUlated) IN 90

\begin{tabular}{lcc}
\multicolumn{3}{c}{ DAYS } \\
\hline \hline $\begin{array}{c}\text { Period of } \\
\text { storage } \\
\text { (day) }\end{array}$ & $\begin{array}{c}\text { No.of survival } \\
(\text { mean } \pm \text { SE })\end{array}$ & Survival rate $(\%)$ \\
\hline 0 & $30.00 \pm 0.00 \mathrm{a}$ & $100.00 \pm 0.00 \mathrm{a}$ \\
15 & $28.81 \pm 0.32 \mathrm{a}$ & $98.73 \pm 0.51 \mathrm{a}$ \\
30 & $27.61 \pm 1.10 \mathrm{~b}$ & $93.32 \pm 0.51 \mathrm{a}$ \\
45 & $26.42 \pm 0.63 \mathrm{~b}$ & $88.04 \pm 1.02 \mathrm{c}$ \\
60 & $23.12 \pm 1.32 \mathrm{c}$ & $77.03 \pm 1.01 \mathrm{~b}$ \\
75 & $20.31 \pm 0.20 \mathrm{c}$ & $60.03 \pm 1.52 \mathrm{c}$ \\
90 & $16.34 \pm 0.82 \mathrm{~d}$ & $53.33 \pm 1.22 \mathrm{c}$ \\
\hline \hline
\end{tabular}

*Each value represents the mean \pm SE of 30 replicates. The mean with different letters in the same column differ significantly at $p \leq 0.05$.

Biotechnology has emerged as a strong tool in mass propagation and improvement of all plant species. Clonal multiplication is production of true to type plants in large number, in a short period of time. It offers a method to increase valuable genotype rapidly and expedite the release of large numbers of plantlets. To fulfil the increasing demand of this potent medicinal plant, in vitro culture is an alternative method for conservation of this diminishing plant population [21] through production of artificial seeds [22].

Interestingly, synthetic seeds that was stored prior to being cultured showed significantly higher conversion frequency than synthetic seeds directly sown on MS basal media (control). Higher percentage of survival was also recorded when the synthetic seeds were stored prior to being cultured on MS basal media compared to the control. It was also observed that storage period of 60 days was the most optimum to ensure a high plantlet conversion rate and survival percentage. Shoot formation was also the highest from synthetic seeds stored for 30 days. This was clearly demonstrated in Table I.

TABLE III: SYNTHETIC SEEDS GERMINATION OF CLITORIA TERNATEA ON DIFFERENT SOWING SUBSTRATES

\begin{tabular}{lll}
\hline \hline Sowing substrates & \multicolumn{1}{c}{ Treatment } & \multicolumn{1}{c}{ Observation } \\
\hline $\begin{array}{l}\text { Solid Murashige } \\
\text { and Skoog media } \\
\text { (MS) }\end{array}$ & $\begin{array}{l}\text { Supplemented with 1.0 } \\
\text { mg/l NAA, 0.5 mg/l BA } \\
\text { and 40 mg/l adenine }\end{array}$ & $\begin{array}{l}\text { Encapsulated beads } \\
\text { regenerated } \\
\text { to complete plantlets }\end{array}$ \\
$\begin{array}{l}\text { Sterilled } \\
\text { garden soil }\end{array}$ & $\begin{array}{l}\text { Moistened with distilled } \\
\text { water }\end{array}$ & $\begin{array}{l}\text { Encapsulated beads } \\
\text { became shrunk and the } \\
\text { explant died }\end{array}$ \\
$\begin{array}{l}\text { Non-sterilled black } \\
\text { garden soil }\end{array}$ & $\begin{array}{l}\text { Moistened with distilled } \\
\text { water }\end{array}$ & $\begin{array}{l}\text { Encapsulated beads } \\
\text { became shrunk and } \\
\text { contaminated }\end{array}$ \\
\hline \hline
\end{tabular}
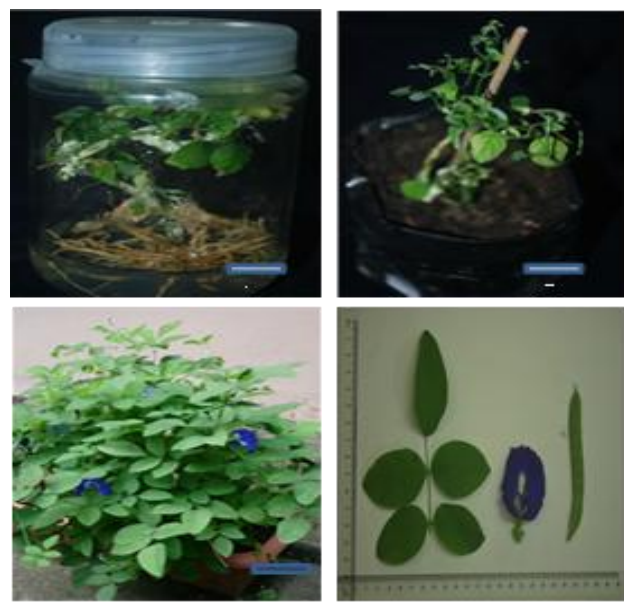

Fig. 3. A) 6-month-old plantlet of Clitoria ternatea L.with formation of primary roots on MS basal medium, B) Shoots elongation after two months being acclimatized, C) Vivid blue flowers formation after six months being acclimatized, D) Morphological of leaf, flower and fruit were similar to mother plant.

Table III indicates various media or substrates tested for germination of the synthetic seeds. The optimum substrate was MS basal medium (Fig. 1 and Fig. 2). After four weeks, the microshoots elongated and eventually undergone complete regeneration. Other sowing substrates were shown to produce poorer results when compared to MS basal media. Substrates moistened with only distilled water resulted in shrinking of the synthetic seeds, while substrates moistened with liquid MS without sucrose resulted in fungal contamination. Finally, the plantlets regenerated from synthetic seeds sowed on MS basal media were successfully acclimatized in the garden.

\section{CONCLUSION}

In the present study, production of encapsulated or synthetic seeds was attempted from Clitoria ternatea L. and managed to survive for 90 days after storage at $4^{\circ} \mathrm{C}$. The highest survival rate of synthetic seeds of Clitoria ternatea was $100 \%$ on MS media supplemented with combination of $1.0 \mathrm{mg} / \mathrm{l} \mathrm{NAA}, 0.5 \mathrm{mg} / \mathrm{l} \mathrm{BA}$ and $40 \mathrm{mg} / \mathrm{l}$ adenine. While, the lowest $(53.33 \pm 1.22 \%)$ after 90 days.

\section{ACKNOWLEDGMENT}

The authors would like to thank University of Malaya, 
Kuala Lumpur, Malaysia, for Postgraduate Research Grant, IPPP (PG071/2013B) and University Malaya Research Grant, UMRG (RP025/2012A).

\section{REFERENCES}

[1] J. B. Morris, "Legume genetic resources with novel 'value added' industrial and pharmaceutical use," Perspectives on New Crops and New Uses, Alexandria, VA, USA: ASHS Press, pp. 196-201, 1999.

[2] USDA, "National genetic resources program, GRIN taxonomy for plants," National Germplasm Resources Laboratory, Beltsville, Maryland, 2014.

[3] L. D. Kapoor, Hand Book of Indian Medicinal Plants, CRC Press, pp. 126-127, 2001

[4] B. K. Srivastava and C. S. Pandey, "Anthocyanins from the flowers of Clitoria ternatea," Planta Med., vol. 32, pp. 138-140, 1977.

[5] N. N. Jain, C. C. Ohal, S. K. Shroff., R. H. Bhutada, R. S. Somani, V. S Kasture, and S. B. Kasture, "Clitoria ternatea and the CNS," Pharmacol. Biochem. Behavior, vol. 75, pp. 529-536, 2003.

[6] C. Kulkarni, J. R. Pattanshetty, and G. Amruthraj, "Effect of alcoholic extract of Clitoria ternatea Linn. on central nervous system in rodents," Indian J. Exp. Biol., vol. 26, pp. 957-960, 1988.

[7] K. R. Kirtikar and B. D. Basu, "Indian medicinal plants," Allahabad, vol. 1 , no. 2, pp. 802-804, 1981.

[8] T. Mossman, "Rapid colorimetric assay for cellular growth and survival: Application to proliferation and cytotoxicity assays," $J$. Immunol. Methods, vol. 65, pp. 55-63, 1983.

[9] R. M. Taha, A. Saleh, N. Mahmad, N. A. Hasbullah, and S. Mohajer, "Germination and plantlet regeneration of encapsulated microshoots of aromatic rice," The Scientific World Journal, 2012.

[10] N. Mohamed and R. M. Taha, "Plant regeneration of Clitoria ternatea from leaf explants cultured in vitro," Journal of Food, Agriculture \& Environment, vol. 9, no. 3, 4, pp. 268-270, 2011.

[11] S. Mohajer and R. M. Taha, "Induction of different types of callus and somatic embryogenesis in various explants of Sainfoin (Onobrychis sativa)," Australian Journal of Crop Science, vol. 6, no. 8, pp. 1305-1313, 2012.

[12] M. Arumugam and R. Panneerselvam, "In vitro propagation and antibacterial activity of Clitoria ternatea Linn.," Asian Pacific Journal of Tropical Biomedicine, pp. 870-875, 2012.

[13] S. Mukhtar, M. Anis, and N. Ahmad, "In vitro optimization of phytohormones on micropropagation in butterfly pea (Clitoria ternatea L.)," Journal of Herbs, Spices \& Medicinal Plants, vol. 16, no. 2, pp. 98-105, 2010.

[14] G. K. Kumar and T. D. Thomas, "High frequency somatic embryogenesis and synthetic seed production in Clitoria ternatea Linn," Plant Cell, Tissue and Organ Culture. vol. 110, no. 1, pp. 141-151, 2012.

[15] T. Murashige and F. Skoog, "A revised medium for rapid growth and bioassays with tobacco tissue cultures," Physiol Plant. vol. 15, pp. 473-497, 1962.

[16] S. Y. Kim, Y. He, Y. Jacob, Y. S. Noh, S. Michaels, and R. Amasino, "Establishment of the vernalization-responsive, winter-annual habit in Arabidopsis requires a putative histone $\mathrm{H} 3$ methyl transferase," Plant Cell, vol. 17, pp. 3301-3310, 2006.

[17] J. E. Preece and T. P. West, "Greenhouse growth and acclimatization of encapsulated Hibiscus moscheutos nodal segments," Plant Cell Tiss Organ Cult., vol. 87, pp. 127-138, 2006.

[18] V. A. Bapat and P. S. Rao, "In vitro growth of encapsulated axillary buds of mulberry (Morusindica L.)," Plant Cell Tissue Org. Cult, vol. 20, pp. 69-70, 1990.

[19] Ramakrishnappa, "Studies on somatic embryogenesis and production of synthetic seeds in Gladiolus cultivars," Ph. D. Thesis, Univ. Agric. Sci., Bangalore, 1998.

[20] A. Awal, A. Bakrudeen A. Ahmed, R. M. Taha, J. S. Yaacob, and S. Mohajer, "Effect of adenine, sucrose and plant growth regulators on the indirect organogenesis and on in vitro flowering in Begonia $x$ hiemalis Fotsch," Australian Journal of Crop Science, vol. 7, no. 5, pp. 691-698, 2013.

[21] N. Ismail, U. Rani, and A. Batra, "High frequency in vitro shoot regeneration of Clitoria ternatea L. affected by different cultural conditions," Indian Journal of Biotechnology, vol. 11, pp. 2010-2014, 2012.

[22] P. K. Siong, S. Mohajer, and R. M. Taha, "Production of artificial seeds derived from encapsulated in vitro micro shoots of cauliflower, Brassica oleracea var. botrytis," Romanian Biotechnological Letters, vol. 17, pp. 7549-7556, 2012.

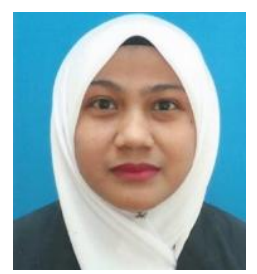

Noraini Mahmad was born in Kelantan, Malaysia on January 24, 1977. She obtained her B.Sc in biotechnology in 2000 from University of Malaya, Malaysia. Eventually in 2012, she obtained her M.Sc in biotechnology from University of Malaya Malaysia. She is currently pursuing her Ph.D also at Institute of Biological Sciences, Faculty of Science, University of Malaya, Kuala Lumpur, Malaysia.

Until now, she had authored 7 scientific articles published in ISI-cited journals. She also had participated in several conferences such as " 1 st International Symposium on Sustainable Vegetable Production in South East Asia (2011)" and "Innovative Trends in Multidisciplinary Academic Research (2014)" in Istanbul, Turkey.

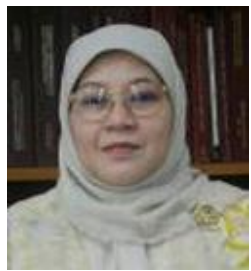

Rosna Mat Taha was born in Malaysia on January 22, 1958. In 1984, she obtained her B.Sc. in botany from University of Malaya, Kuala Lumpur, Malaysia and eventually completed her Ph.D in 1989 in plant morphogenesis from University of Wales, Cardiff, UK.

She is currently working as a lecturer (professor) at Institute of Biological Sciences, Faculty of Science, University of Malaya, Kuala Lumpur, Malaysia. Prof. Dr. Rosna Mat Taha has published more than 150 papers in ISI-cited journals, proceedings, book chapters and etc.

Prof. Taha is also an expert in plant tissue culture, morphogenesis, biotechnology, pigment and cellular behavior studies. She has won many awards (more than 40) in her research. She is a member of European Association for Reserach on Plant Breeding (EUCARPIA) and International Society for Horticultural Science (ISHS). Also, she is the associate editor of Asian Journal of Biotechnology, Asian Journal of Plant Sciences and Journal of Applied Sciences.

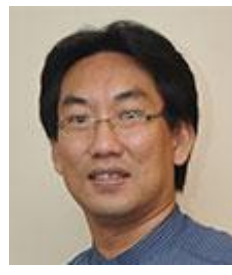

Zealand.

He is currently a certified horticulturist at the Department of Landscape Architecture. His research interests include horticulture, landscape ecology, environmental sciences, and ethno-botany relating to the Halal industry.

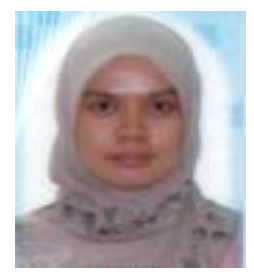

Hashimah Elias was born in Sarawak, Malaysia on January 17, 1984. She had obtained her B.Sc in biotechnology in 2007 and currently pursuing her $\mathrm{Ph} . \mathrm{D}$ in plant biotechnology at the same place, Institute of Biological Sciences, Faculty of Science, University of Malaya, Malaysia.

She had experienced as a research assistant (2007-2009) and has contributed in tutoring and demonstrating since 2009 onwards also at University of Malaya, Malaysia. To date, she had participated in 6 international conferences and 9 exhibitions in related fields. Recently, she has published 1 scientific article in ISI-cited journal.

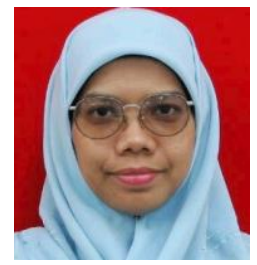

Azani Saleh was born in Kota Bharu, Kelantan, Malaysia in 1966. She received her B. Sc. in botany from University of Malaya, Kuala Lumpur, Malaysia in 1991 and eventually completed her M.Sc. in plant physiology in 1995 from the same university. Azani is currently pursuing her $\mathrm{PhD}$ in plant biotechnology at Institute of Biological Sciences, University of Malaya, Kuala Lumpur, Malaysia.

She started her career as a lecturer in 1996, where she taught biology subject for Matriculation Program in Kolej Poly-Tech MARA. She is now a senior lecturer in MARA University of Technology (UiTM), Selangor, Malaysia. She frequently taught Human Biology, Molecular Biology and Biochemistry. Currently, she is the Project Coordinator for final year students of Bachelor of Science (Hons) in Biology. She has published many scientific research articles in ISI indexed Journals. Her area of interest includes plant biotechnology, plant physiology, and soil science. Azani Saleh is a member of International Society for Horticultural Science (ISHS). She had participated and won several awards in various conferences and exhibitions. 